\title{
Polymorphisms of Receptor for Advanced Glycation end Products and Risk of Epithelial Ovarian Cancer in Chinese Patients
}

\author{
Shuquan Zhang ${ }^{a}$ Xuwei Hou ${ }^{b}$ Sihua Zi ${ }^{a}$ Yankui Wang ${ }^{c}$ Lijun Chen ${ }^{a}$ Beihua Kong ${ }^{a}$ \\ aDepartment of Obstetrics and Gynecology, Qilu Hospital, Shandong University, Jinan, Shandong \\ province; 'Department of Cardiology, Hangzhou First Municipal Hospital \& Hangzhou Hospital, \\ Nanjing Medical University, Hangzhou; 'Department of Obstetrics and Gynecology, the Affiliated \\ Hospital of QingDao University Medical College, Jinan, Shandong province
}

\section{Key Words}

Receptor for advanced glycation end products - Epithelial ovarian carcinoma $•$ Polymorphisms - Risk

\begin{abstract}
Background: Given the roles of receptor for advanced glycation end products (RAGE) in the pathogenesis of carcinogenesis, we propose that RAGE polymorphisms may be associated with risk of epithelial ovarian carcinoma (EOC). Method: This case-control study included 190 women over 40 years of age who were diagnosed with primary EOC and 210 healthy control subjects. RAGE gene polymorphisms, including $82 \mathrm{G}>\mathrm{S},-374 \mathrm{~T}>\mathrm{A},-429 \mathrm{C}>\mathrm{T}$, and $1704 \mathrm{G}>\mathrm{T}$ were determined. Results: We found that only the frequencies of the $82 \mathrm{G}>\mathrm{S}$ polymorphisms were significantly different between the EOC cases and controls. The 82SS genotype was significantly higher in EOC patients than in controls $(37.89 \%$ vs. $23.33 \%, \mathrm{P}<0.001)$. With the 82 GG genotype as reference, the OR for 82 SS homozygous carriers reached to 2.65 (95\% CI: 1.54-4.58; $\mathrm{P}=0.0004$ ) after adjustment for age, smoking status, body mass index, family history, usage of contraceptives, tubal ligation history, use of menopausal hormones and menopausal status. The $82 \mathrm{~S}$ allele carriage presented a higher risk for $\mathrm{EOC}(\mathrm{OR}=1.71 ; 95 \% \mathrm{CI}$, 1.29-2.26; $\mathrm{P}=0.0002$ ). The polymorphisms of $1704 \mathrm{G}>\mathrm{T},-374 \mathrm{~T}>\mathrm{A}$ and $-429 \mathrm{C}>\mathrm{T}$ did not affect the EOC risk. Conclusion: This result suggests that the $82 \mathrm{G}>\mathrm{S}$ polymorphism of RAGE gene may be associated with the susceptibility of EOC.
\end{abstract}


Zhang/Hou/Zi/Wang/Chen/Kong: RAGE Polymorphism and EOC Risk

\section{Introduction}

Epithelial ovarian cancer (EOC) is the most common type of ovarian cancer in human [1]. To date, the pathogenesis of EOC is still not fully understood. The role of genetic background in the etiology and pathogenesis of EOC has been documented [2,3]. Given that most cases present with advanced, incurable disease, high-risk women should be targeted for primary prevention and early detection. Several genetic polymorphisms have been reported to be involved in the development of EOC [4-6]. However, the documented genetic variants associated with EOC are limited, and more studies need be performed to elucidate the genetic mechanisms underlying EOC.

The receptor for advanced glycation end products (RAGE) is a member of the immunoglobulin superfamily of cell surface molecules and a receptor for advanced glycation end products (AGEs) [7, 8]. AGE-RAGE interaction alters several cell functions through modulation of multiple intracellular signaling pathways [9]. Accumulating evidence revealed that RAGE plays an important role in the pathogenesis and progression of cancer by promoting cancer cell migration, differentiation and invasion [10-12]. Clinical studies suggests that RAGE level may be used as a new biomarker for some type of cancers including lung cancer [13], breast cancer [14],prostate cancer [15], colorectal cancer [16].

The RAGE gene is found on chromosome $6 \mathrm{p} 21.3$ in the major histocompatability locus (MHC) locus class II/III junction and is composed of a 1.7-kb $5^{\prime}$ flanking region and 11 exons. To date, several genetic variants have been identified in RAGE gene, including 82 $\mathrm{G}>\mathrm{S}$ (rs2070600), -429C > T (rs1800625), -374 T>A (rs1800624) and 1704G $>\mathrm{T}$ (rs184003). Pervious studies documented positive associations between the genetic variants of RAGE and a variety of cancers, including gastric cancer [17], pancreas cancer [18] and breast cancer [14], however, no study regarding the role of RAGE genetic variants in EOC was reported. Given the roles of RAGE in the pathogenesis of carcinogenesis, we proposed that the RAGE genetic polymorphisms might be related to the risk of EOC. In present study, we performed a case-control study in a Chinese cohort to test the hypothesis.

\section{Materials and Methods}

\section{Study population}

This case-control study included 190 women over 40 years old who were diagnosed with primary histologically-confirmed EOC between Aug 2002 and Aug 2008 in our hospital. A total of 210 age-matched healthy control subjects were recruited as control. Socio-demographic, lifestyle, and health-related information, e.g. age, sex, body mass index, smoking status, cancer family history, use of oral contraceptives, menopausal status, had or had not tubal ligation, use of menopausal hormones were collected by using a structured questionnaire. The Institutional Review Board of the Shandong University approved the study protocol. All the participants provided written informed consent.

\section{RAGE genotyping}

Venous blood was collected from each patient into tubes containing $50 \mathrm{mmol}$ of EDTA per liter, and genomic DNA was isolated with DNA blood Mini kit, according to manufacturer's instructions. A Polymerase Chain Reaction -Restriction Fragment Length Polymorphism (PCR-RFLP) assay was used to determine the RAGE polymorphisms. The detection of RAGE genetic polymorphisms of $82 \mathrm{G}>\mathrm{S},-374 \mathrm{~T}>\mathrm{A},-429 \mathrm{C}>\mathrm{T}$, and $1704 \mathrm{G}>\mathrm{T}$ were performed as described previously $[19,20]$.

\section{Statistical analysis}

$\chi 2$ tests were used to compare genotype frequency and demographic distributions between cases and controls. Multiple logistic regression analyses were used to evaluate if each polymorphism was independently associated with EOC risk with adjustment of the potential confounding effects of clinical variables. The odds ratios (OR) and 95\% confidence intervals (CIs) were calculated. All analyses were performed by using SPSS software (Statistical Package for the Social Sciences, version 16.0, SPSS Inc, 


\begin{tabular}{|c|c|c|c|}
\hline & EOC & Control & \\
\hline $\operatorname{Age}(y)$ & $53.55 \pm 3.8$ & $53.45 \pm 4.6$ & 0.582 \\
\hline \multicolumn{4}{|l|}{ body mass index (kg/m2) } \\
\hline Underweight(BMI<18.5) & 25 & 31 & \multirow[t]{4}{*}{0.719} \\
\hline Normal(BMI:18.5-25) & 44 & 54 & \\
\hline Overweight(BMI:25-30) & 67 & 63 & \\
\hline Obesity(BMI>30) & 54 & 62 & \\
\hline \multicolumn{4}{|l|}{ Smoking } \\
\hline Never Smoker & 34 & 57 & \multirow[t]{3}{*}{0.081} \\
\hline Past smoker & 78 & 80 & \\
\hline Current smoker & 78 & 73 & \\
\hline \multicolumn{4}{|l|}{ Cancer family history } \\
\hline Yes & 56 & 30 & \multirow[t]{2}{*}{0.001} \\
\hline No & 134 & 180 & \\
\hline \multicolumn{4}{|l|}{ Use of oral contraceptives } \\
\hline Yes & 88 & 77 & \multirow[t]{2}{*}{0.032} \\
\hline No & 102 & 133 & \\
\hline \multicolumn{4}{|l|}{ Had tubal ligation } \\
\hline Yes & 61 & 67 & \multirow[t]{2}{*}{0.525} \\
\hline No & 129 & 143 & \\
\hline \multicolumn{4}{|l|}{ Menopausal status } \\
\hline Premenopausal & 50 & 57 & \multirow[t]{2}{*}{0.471} \\
\hline Postmenopausal & 140 & 153 & \\
\hline \multicolumn{4}{|c|}{ Use of menopausal hormones } \\
\hline Never used & 101 & 121 & \multirow[t]{4}{*}{0.302} \\
\hline Estrogen only & 45 & 35 & \\
\hline Progesterone only & 34 & 45 & \\
\hline Estrogen+Progesterone & 10 & 9 & \\
\hline
\end{tabular}

Table 1. The clinico-pathologic characteristics of the cohort

Chicago, IL, USA). The D' value for the genetic polymorphisms of $82 \mathrm{G}>\mathrm{S},-374>\mathrm{A},-429 \mathrm{C}>\mathrm{T}$, and $1704 \mathrm{G}>\mathrm{T}$ were calculated with the SHEsis software [21].

\section{Results}

The clinical characteristics of all participants are summarized in Table 1. The EOC and healthy control groups were similar in age, body mass index, smoking status, tubal ligation, monepausal status and use of menopausal hormones. The EOC patients had a higher rate of cancer family history and use of oral contraceptives (both $\mathrm{P}<0.05$ ).

The genotype distributions of the genetic polymorphisms of $82 \mathrm{G}>\mathrm{S},-374>\mathrm{A},-429 \mathrm{C}>\mathrm{T}$, and $1704 \mathrm{G}>\mathrm{T}$ were in agreement with Hardy-Weinberg equilibrium for both cases and controls (both $\mathrm{P}>0.05$ ). The 82SS genotype was significantly higher in EOC patients than in controls $(37.89 \%$ vs. $23.33 \%, \mathrm{P}<0.001)$. Furthermore, the $82 \mathrm{~S}$ allele frequency was significantly higher in the case group than in the control group $(59.47 \%$ vs. $46.19 \%$, $\mathrm{P}<0.001$ ). In contrast, no significant differences in the genotype frequencies of $1704 \mathrm{G}>\mathrm{T}$,$374 \mathrm{~T}>\mathrm{A}$ and $-429 \mathrm{C}>\mathrm{T}$ were noted between EOC and control groups (all $\mathrm{P}>0.05$ ). We further performed the multivariate logistic regression to determine the independent risk factors for EOC. With the 82 GG genotype as reference, the adjusted OR for 82SS homozygous carriers 


\begin{tabular}{lccccccccccc}
\hline Genotype & $\mathrm{N}$ & $\%$ & $\mathrm{~N}$ & $\%$ & $\begin{array}{c}\text { P } \\
\text { trend }\end{array}$ & $\begin{array}{c}\text { adjusted } \\
\text { OR }\end{array}$ & 95\%CI & $\mathrm{X}^{2}$ & $\begin{array}{c}\text { adjusted } \\
\mathrm{P}\end{array}$ & Power \\
\hline $82 \mathrm{GG}$ & 36 & $18.95 \%$ & 65 & $30.95 \%$ & $<0.001$ & 1 & & & & & \\
$82 \mathrm{GS}$ & 82 & $43.16 \%$ & 96 & $45.71 \%$ & & 1.54 & 0.93 & 2.55 & 2.87 & 0.0903 & 0.39 \\
$82 \mathrm{SS}$ & 72 & $37.89 \%$ & 49 & $23.33 \%$ & & 2.65 & 1.54 & 4.58 & 12.55 & 0.0004 & 0.94 \\
$82 \mathrm{G}$ & 154 & $40.53 \%$ & 226 & $53.81 \%$ & $<0.001$ & 1 & & & & & \\
$82 \mathrm{~S}$ & 226 & $59.47 \%$ & 194 & $46.19 \%$ & & 1.71 & 1.29 & 2.26 & 14.12 & 0.0002 & 0.96 \\
\hline
\end{tabular}

Table 2. Data for genotype distribution and allele frequencies of $82 \mathrm{G}>\mathrm{S}$ between EOC subjects and controls

\begin{tabular}{cccccccc}
\hline $1704 \mathrm{G}>\mathrm{T}$ & $-374 \mathrm{~T}>\mathrm{A}$ & $82 \mathrm{G}>\mathrm{S}$ & $-429 \mathrm{C}>\mathrm{T}$ & Case(freq) & Control(freq) & $\mathrm{P}$ & Odds Ratio [95\%CI] \\
\hline $\mathrm{G}$ & $\mathrm{A}$ & $\mathrm{S}$ & $\mathrm{C}$ & 54 & 15 & 0.00126 & $2.569[1.399 \sim 4.286]$ \\
$\mathrm{G}$ & $\mathrm{T}$ & $\mathrm{S}$ & $\mathrm{C}$ & 33 & 37 & 0.543 & $0.943[0.707 \sim 1.698]$ \\
$\mathrm{T}$ & $\mathrm{A}$ & $\mathrm{S}$ & $\mathrm{T}$ & 44 & 31 & 0.0214 & $1.569[1.0131 \sim 2.986]$ \\
$\mathrm{G}$ & $\mathrm{T}$ & $\mathrm{G}$ & $\mathrm{T}$ & 35 & 38 & 0.117 & $0.893[0.717 \sim 1.924]$ \\
$\mathrm{T}$ & $\mathrm{T}$ & $\mathrm{G}$ & $\mathrm{T}$ & 32 & 55 & 0.0017 & $0.523[0.217 \sim 0.924]$ \\
\hline
\end{tabular}

Table 3. The estimated haplotype frequencies of the RAGE genetic polymorphisms in EOC patients and controls

reached to 2.65 (95\% CI: 1.54-4.58; $\mathrm{P}=0.0004$, power value 0.94 ) after adjustment for age, smoking status, BMI, family history, usage of contraceptives, tubal ligation history, use of menopausal hormones and menopausal status, while the adjusted OR for the 82GS genotype was $1.54(\mathrm{P}=0.0903)$. The $82 \mathrm{~S}$ allele carriage also presented a higher risk for EOC (adjusted $\mathrm{OR}=1.71$; $95 \% \mathrm{CI}, 1.29-2.26$; adjusted $\mathrm{P}=0.0002$, power value 0.96 ). The polymorphisms of $1704 \mathrm{G}>\mathrm{T},-374 \mathrm{~T}>\mathrm{A}$ and $-429 \mathrm{C}>\mathrm{T}$ did not affect the EOC risk in logistic regression (data not shown).

The associations between the RAGE haplotypes and the risk for EOC were analyzed in this study. The D' values for the studied genetic polymorphisms were calculated with the SHEsis software. All the studied RAGE genetic polymorphisms were in strong LD (all $D^{\prime}>0.8$ ). The estimated haplotype frequencies of the RAGE SNPs in the patients with EOC and controls are shown in Table 3. The haplotype of $\mathrm{G}_{1704}-\mathrm{A}_{-374}-\mathrm{S}_{82} \mathrm{C}_{-429}$ showed a significantly higher risk for EOC $(\mathrm{OR}=2.569,95 \% \mathrm{CI}: 1.399 \sim 4.286, \mathrm{P}=0.00126)$. The haplotype of $\mathrm{T}_{1704}{ }^{-}$ $\mathrm{A}_{-374}-\mathrm{S}_{82}-\mathrm{T}_{-429}$ represented a higher risk for EOC as well (OR=1.569, 95\% CI: 1.0131 2.986, $\mathrm{P}=0.0214)$. Meanwhile, the $\mathrm{T}_{1704}-\mathrm{T}_{-374}-\mathrm{G}_{82}-\mathrm{T}_{-429}$ had a lower risk for EOC (OR=0.523, 95\% CI: $0.217 \sim 0.924, \mathrm{p}=0.0117$ ).

\section{Discussion}

In the present study, we found that $82 \mathrm{G}>\mathrm{S}$ variants were significantly associated with the risk of EOC in a Chinese cohort. The 82SS genotype carriers presented a 2.65 times higher risk for EOC than $82 \mathrm{GG}$ genotype carriers. These results suggest that the $82 \mathrm{G}>\mathrm{S}$ polymorphisms of RAGE gene may be used as genetic marker for EOC occurrence. In addition, we also found that the haplotype G1704-A-374-S82-C-429 and T1704-A-374-S82-T-429 represented higher risk for EOC.

RAGE is encoded by chromosome 6 at the major MHC class II/III junction. To date, more than 20 several single nucleotide polymorphisms in the RAGE gene have been identified [22]. Some genetic variants in the RAGE gene could alter the expression and function of RAGE, thus affect disease development [22]. One of the most frequently studied and relatively high prevalence variants is the $82 \mathrm{G}>\mathrm{S} \mathrm{r}$ (Gly82Se) polymorphism. It is at codon 82 (GGC $\rightarrow \mathrm{AGC}$ ) in exon 3 of $R A G E$ and leads to a change from glycine to serine within the putative ligand- 
binding domain of the protein and it has been proposed as a functional polymorphism and associated with enhanced RAGE signaling [23]. Recent observations indicated that the $82 \mathrm{G}>\mathrm{S}$ polymorphism was associated with various diseases, including skin complications in type 2 diabetes, diabetic advanced nephropathy and coronary artery disease [23-26].

Several previous studies explored the role of $82 \mathrm{G}>\mathrm{S}$ polymorphism of $R A G E$ gene in carcinogenesis in Chinese population. The polymorphism of $\mathrm{G}>\mathrm{S}$ was reported to be associated with the increased risk of gastric cancer and a significant correlation of the RAGE variant genotypes with adjacent organ invasion [17]. In that study, the genotype frequency was $50.18 \%$ for GG, $44.52 \%$ for GS and $5.3 \%$ for SS. In another study in patients with nonsmall cell lung cancer, the 82SS genotype not only increased the lung cancer risk, but also related to a lower chemotherapy response rate and poor prognosis. The GG frequency in lung cancer patients were $14.95 \%$ for GG, $64.06 \%$ for GS and 21.00 for SS [27]. A recent published study showed that $82 \mathrm{SS}$ is associated with the cervical cancer in Chinese patients. The cervical cancer patients had a markedly higher percentage of 82SS carriage than controls. The 82SS genotype was associated with elevated risk for cervical cancer. In addition, the 82SS carriers had significantly lower serum soluble RAGE levels than 82GS and 82GG[28]. In the present study, we observed the $82 \mathrm{G}>\mathrm{S}$ genotype frequencies were: GG: $18.95 \%, \mathrm{GS}$ : $43.16 \%$, SS: $37.89 \%$. The $82 \mathrm{G}>\mathrm{S}$ genotype distribution in our study was consistent with the genotype frequencies from cervical cancer [28]. Consistent with the results from Chinese cervical cancer patients, our study also suggests that carriage of 82SS genotype of $82 \mathrm{G}>\mathrm{S}$ polymorphism predicts a significantly higher risk for EOC incidence.

It was reported that soluble RAGE concentration was significantly higher in subjects with the $82 \mathrm{GG}$ genotype $(1,038 \pm 33 \mathrm{pg} / \mathrm{mL})$ than in those with the $82 \mathrm{GS}(809 \pm 19 \mathrm{pg} / \mathrm{mL})$ or the $82 \mathrm{SS}(428 \pm 43 \mathrm{pg} / \mathrm{mL}$ ) genotype [29]. The $82 \mathrm{G}>\mathrm{S}$ variant also was significantly influence the serum inflammatory marker, such as $\mathrm{C}$ reaction protein level in the Chinese Han population with coronary heart disease [30]. Factors contributing to chronic inflammation appear to be associated with increased risk of ovarian cancer [31]. A recent study assessed the association between circulating levels of inflammation mediators and subsequent risk of ovarian cancer. The authors found that inflammation markers, specifically interleukins, were associated with higher risk for EOC [32]. This study adds new evidence that inflammation is involved in the development of EOC. Based on the above-mentioned study, we postulate that the $82 \mathrm{G}>\mathrm{S}$ genetic polymorphism may determine the EOC risk by influencing the inflammation status of carriers. Our future study will focus on the expression of inflammation mediators at serum and tissue level to better elucidate the association between the RAGE $82 \mathrm{G}>\mathrm{S}$ polymorphism and EOC risk.

\section{Acknowledgements}

We thank Dr. and Mrs. Luther H Fulcher, Jr. for their help with the language revision of this manuscript.

\section{References}

Jemal A, Siegel R, Xu J, Ward E: Cancer statistics, 2010. CA Cancer J Clin 2010;60:277-300.

Fasching PA, Gayther S, Pearce L, Schildkraut JM, Goode E, Thiel F, Chenevix-Trench G, Chang-Claude J, Wang-Gohrke S, Ramus S, Pharoah P, Berchuck A: Role of genetic polymorphisms and ovarian cancer susceptibility. Mol Oncol 2009;3:171-181.

- 3 Berchuck A, Schildkraut JM, Pearce CL, Chenevix-Trench G, Pharoah PD: Role of genetic polymorphisms in ovarian cancer susceptibility: Development of an international ovarian cancer association consortium. Adv Exp Med Biol 2008;622:53-67.

4 Ma X, Zhang J, Liu S, Huang Y, Chen B, Wang D: Polymorphisms in the casp8 gene and the risk of epithelial ovarian cancer. Gynecol Oncol 2011;122:554-559. 
Zhang/Hou/Zi/Wang/Chen/Kong: RAGE Polymorphism and EOC Risk

5 Goode EL, White KL, Vierkant RA, Phelan CM, Cunningham JM, Schildkraut JM, Berchuck A, Larson MC, Fridley BL, Olson JE, Webb PM, Chen X, Beesley J, Chenevix-Trench G, Sellers TA: Xenobiotic-metabolizing gene polymorphisms and ovarian cancer risk. Mol Carcinog 2011;50:397-402.

6 Pharoah PD, Palmieri RT, Ramus SJ, Gayther SA, Andrulis IL, Anton-Culver H, Antonenkova N, Antoniou AC, Goldgar D, Beattie MS, Beckmann MW, Birrer MJ, Bogdanova N, Bolton KL, Brewster W, Brooks-Wilson A, Brown R, Butzow R, Caldes T, Caligo MA, Campbell I, Chang-Claude J, Chen YA, Cook LS, Couch FJ, Cramer DW, Cunningham JM, Despierre E, Doherty JA, Dork T, Durst M, Eccles DM, Ekici AB, Easton D, Fasching PA, de Fazio A, Fenstermacher DA, Flanagan JM, Fridley BL, Friedman E, Gao B, Sinilnikova O, Gentry-Maharaj A, Godwin AK, Goode EL, Goodman MT, Gross J, Hansen TV, Harnett P, Rookus M, Heikkinen T, Hein R, Hogdall C, Hogdall E, Iversen ES, Jakubowska A, Johnatty SE, Karlan BY, Kauff ND, Kaye SB, Chenevix-Trench G, Kelemen LE, Kiemeney LA, Kjaer SK, Lambrechts D, Lapolla JP, Lazaro C, Le ND, Leminen A, Leunen K, Levine DA, Lu Y, Lundvall L, Macgregor S, Marees T, Massuger LF, McLaughlin JR, Menon U, Montagna M, Moysich KB, Narod SA, Nathanson KL, Nedergaard L, Ness RB, Nevanlinna H, Nickels S, Osorio A, Paul J, Pearce CL, Phelan CM, Pike MC, Radice P, Rossing MA, Schildkraut JM, Sellers TA, Singer CF, Song H, Stram DO, Sutphen R, Lindblom A, Terry KL, Tsai YY, van Altena AM, Vergote I, Vierkant RA, Vitonis AF, Walsh C, Wang-Gohrke S, Wappenschmidt B, Wu AH, Ziogas A, Berchuck A, Risch HA: The role of kras rs61764370 in invasive epithelial ovarian cancer: Implications for clinical testing. Clin Cancer Res 2011;17:3742-3750.

7 Schmidt AM, Yan SD, Yan SF, Stern DM: The biology of the receptor for advanced glycation end products and its ligands. Biochim Biophys Acta 2000;1498:99-111.

-8 Lindsey JB, Cipollone F, Abdullah SM, McGuire DK: Receptor for advanced glycation end-products (rage) and soluble rage (srage): Cardiovascular implications. Diab Vasc Dis Res 2009;6:7-14.

-9 Lalla E, Lamster IB, Stern DM, Schmidt AM: Receptor for advanced glycation end products, inflammation, and accelerated periodontal disease in diabetes: Mechanisms and insights into therapeutic modalities. Ann Periodontol 2001;6:113-118.

10 Lu B, Song XL, Jia LY, Song FL, Zhao SC, Jiang Y: [differential expressions of the receptor for advanced glycation end products in prostate cancer and normal prostate]. Zhonghua Nan Ke Xue 2010;16:405-409.

11 Takada M, Hirata K, Ajiki T, Suzuki Y, Kuroda Y: Expression of receptor for advanced glycation end products (rage) and mmp-9 in human pancreatic cancer cells. Hepatogastroenterology 2004;51:928-930.

12 Hirata K, Takada M, Suzuki Y, Kuroda Y: Expression of receptor for advanced glycation end products (rage) in human biliary cancer cells. Hepatogastroenterology 2003;50:1205-1207.

13 Jing R, Cui M, Wang J, Wang H: Receptor for advanced glycation end products (rage) soluble form (srage): A new biomarker for lung cancer. Neoplasma 2010;57:55-61.

14 Tesarova P, Kalousova M, Jachymova M, Mestek O, Petruzelka L, Zima T: Receptor for advanced glycation end products (rage)--soluble form (srage) and gene polymorphisms in patients with breast cancer. Cancer Invest 2007;25:720-725.

15 Ishiguro H, Nakaigawa N, Miyoshi Y, Fujinami K, Kubota Y, Uemura H: Receptor for advanced glycation end products (rage) and its ligand, amphoterin are overexpressed and associated with prostate cancer development. Prostate 2005;64:92-100.

-16 Jiao L, Taylor PR, Weinstein SJ, Graubard BI, Virtamo J, Albanes D, Stolzenberg-Solomon RZ: Advanced glycation end products, soluble receptor for advanced glycation end products, and risk of colorectal cancer. Cancer Epidemiol Biomarkers Prev 2011;20:1430-1438.

17 Gu H, Yang L, Sun Q, Zhou B, Tang N, Cong R, Zeng Y, Wang B: Gly82ser polymorphism of the receptor for advanced glycation end products is associated with an increased risk of gastric cancer in a chinese population. Clin Cancer Res 2008;14:3627-3632.

18 Krechler T, Jachymova M, Mestek O, Zak A, Zima T, Kalousova M: Soluble receptor for advanced glycation end-products (srage) and polymorphisms of rage and glyoxalase i genes in patients with pancreas cancer. Clin Biochem 2010;43:882-886.

19 Kalousova M, Jachymova M, Mestek O, Hodkova M, Kazderova M, Tesar V, Zima T: Receptor for advanced glycation end products--soluble form and gene polymorphisms in chronic haemodialysis patients. Nephrol Dial Transplant 2007;22:2020-2026.

20 Kankova K, Zahejsky J, Marova I, Muzik J, Kuhrova V, Blazkova M, Znojil V, Beranek M, Vacha J: Polymorphisms in the rage gene influence susceptibility to diabetes-associated microvascular dermatoses in niddm. J Diabetes Complications 2001;15:185-192. 


\section{Cellular Physiology $\quad$ Cell Physiol Biochem 2013;31:525-531 and Biochemistry \\ Zhang/Hou/Zi/Wang/Chen/Kong: RAGE Polymorphism and EOC Risk}

21 Shi YY, He L: Shesis, a powerful software platform for analyses of linkage disequilibrium, haplotype construction, and genetic association at polymorphism loci. Cell Res 2005;15:97-98.

22 Gaens KH, Ferreira I, van der Kallen CJ, van Greevenbroek MM, Blaak EE, Feskens EJ, Dekker JM, Nijpels G, Heine RJ, 't Hart LM, de Groot PG, Stehouwer CD, Schalkwijk CG: Association of polymorphism in the receptor for advanced glycation end products (rage) gene with circulating rage levels. J Clin Endocrinol Metab 2009;94:5174-5180.

23 Hofmann MA, Drury S, Hudson BI, Gleason MR, Qu W, Lu Y, Lalla E, Chitnis S, Monteiro J, Stickland MH, Bucciarelli LG, Moser B, Moxley G, Itescu S, Grant PJ, Gregersen PK, Stern DM, Schmidt AM: Rage and arthritis: The g82s polymorphism amplifies the inflammatory response. Genes Immun 2002;3:123-135.

24 Kankova K, Vasku A, Hajek D, Zahejsky J, Vasku V: Association of g82s polymorphism in the rage gene with skin complications in type 2 diabetes. Diabetes Care 1999;22:1745.

25 Prevost G, Fajardy I, Besmond C, Balkau B, Tichet J, Fontaine P, Danze PM, Marre M: Polymorphisms of the receptor of advanced glycation endproducts (rage) and the development of nephropathy in type 1 diabetic patients. Diabetes Metab 2005;31:35-39.

-26 Yoon SJ, Park S, Shim CY, Park CM, Ko YG, Choi D, Park HY, Oh B, Kim H, Jang Y, Chung N: Association of rage gene polymorphisms with coronary artery disease in the korean population. Coron Artery Dis 2007;18:1-8.

27 Wang X, Cui E, Zeng H, Hua F, Wang B, Mao W, Feng X: Rage genetic polymorphisms are associated with risk, chemotherapy response and prognosis in patients with advanced NSCLC. PLoS One 2012;7:e43734.

28 Xu Q, Xue F, Yuan B, Zhang L, Li J, He Z: The interaction between rage gene polymorphisms and hpv infection in determining the susceptibility of cervical cancer in a chinese population. Cancer Biomark 2012;11:147-153.

29 Jang Y, Kim JY, Kang SM, Kim JS, Chae JS, Kim OY, Koh SJ, Lee HC, Ahn CW, Song YD, Lee JH: Association of the gly82ser polymorphism in the receptor for advanced glycation end products (rage) gene with circulating levels of soluble rage and inflammatory markers in nondiabetic and nonobese koreans. Metabolism 2007;56:199-205.

30 Gao J, Shao Y, Lai W, Ren H, Xu D: Association of polymorphisms in the rage gene with serum crp levels and coronary artery disease in the chinese han population. J Hum Genet 2010;55:668-675.

-31 Quirk JT, Kupinski JM: Chronic infection, inflammation, and epithelial ovarian cancer. Med Hypotheses 2001;57:426-428.

-32 Clendenen TV, Lundin E, Zeleniuch-Jacquotte A, Koenig KL, Berrino F, Lukanova A, Lokshin AE, Idahl A, Ohlson N, Hallmans G, Krogh V, Sieri S, Muti P, Marrangoni A, Nolen BM, Liu M, Shore RE, Arslan AA: Circulating inflammation markers and risk of epithelial ovarian cancer. Cancer Epidemiol Biomarkers Prev 2011;20:799-810. 